\title{
既存事務所建物における投資のエネルギー低減効果の計測に関する研究 A MEASUREMENT STUDY ON ENERGY CONSERVATION EFFECT OF INVESTMENT IN EXISTING OFFICE BUILDINGS
}

\author{
塩尻康夫*, 石塚義高** \\ Yasuo SHIOJIRI and Yoshitaka ISHIZUKA
}

\begin{abstract}
We attempt to measure energy conservation effect of investment executed after building completion; i.e. investment in mending, repair or renewal. The effect is statistically estimated by means of cross sectional regression analysis, about a little more than one hundred samples of rental office buildings actually working in Tokyo area. In the regression model, energy expenditure variation is assumed to be controlled by revenue variation and investment. The energy conservation effect of investment is estimated as the coefficient of investment in the model. In this analysis, we also consider the influence of scale and age of buildings.
\end{abstract}

Keywords : Office buildings, Investment, Energy conservation, Regression analysis 事務所建物，投資，省エネルギー，回㛿分析

\section{1. はじめに}

\section{1. 先行研究}

建物の運用時のエネルギー消費を低減させる取り組みは、経済性 の向上と環境負荷の低減に有益である。この取り組みは、建物新設 前の設計段階 注1)，1，2，3) において行われることが望ましいが、竣

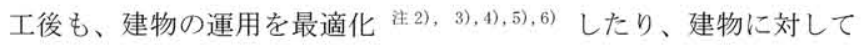
エネルギー低減効果のある投資を行うことが望ましい。

建物の竣工後に行われる投資によるエネルギー低減効果に関する 研究例を掲げる。建物の個別部位への投資についての研究では、住 吉ら ${ }^{7)}$ が、空調熱源のインバータ制御化による環境負荷低減効果に 関して、水田ら ${ }^{8)}$ が、壁・空の断熱改修による環境負荷低減効果に 関して研究している。建物全体の改修に対する投資についての研究 では、杉田ら ${ }^{9)}$ が、事務所建物の事例調查に基づいて、建物の各部 位に一斉に改修が行われた場合の環境負荷低減効果に関して評価す る研究を行っている。

\section{2. 目的と意義}

本論の目的は、事務所建物の拨工後に行われる投資によるエネル ギー低減効果を明らかにすることである。ここで、投資によるエネ ルギー低減効果とは、建物の竣工後において行われる投資額に対す る、その投資によって生じるエネルギー低減額の比、と定義する。 このような投資のエネルギー低減効果を明らかにすることの意義は、 既存の事務所建物の投資が省エネルギーにどれだけ貢献しているか についての一つの知見を得られることである。

投資によるエネルギー低減効果は、投資額全体を通じて均一では なく、含まれている投資の種類によって異なる可能性があるため、 投資の種類別のエネルギー低減効果を計測することも、上記知見を
補強するものとしての意義がある。本論では、投資額を、建物規模 （賃貸可能延面積、以下では延面積という）および時間（竣工後年 数）の関数として回帰分析することにより、投資額の種類別内訳デ 一夕を算定する。この関数で説明される部分は物理的劣化の回復の ための投資を反映し、説明されない部分は、建物仕様、使用状態、 修繥計画などに応じて生じるもので、主として社会的・機能的劣化 の回復のための投資を反映すると考えられる。

以上を踏まえ、具体的に、次のことを目的として分析を進める。

(1) 事務所建物の一定の標本デー夕を用いて、竣工後に行われる投 資によるエネルギー低減効果の標準的な值を計測する。

（2）投資額を、延面積および竣工後年数に応じて実施される部分と、 建物仕様、使用状態、修繥計画の違いによって変動する部分に分 離したうえで、各々の部分のエネルギー低減効果を計測する。

1.3. 分析方法

分析の方法は次のとおりである。

(1) 建物のエネルギー消費額の変動を説明する回帰式を作成する。 回帰式の説明変数は、投資額を含む複数の変数とする。計測目的 である投資のエネルギー低減効果は、回帰式内の投資額の項の係 数によって表される。

（2）実際に稼働している事務所建物の中から、標本となる建物を選 定する。選定した標本建物について、回帰式に含まれる各変数の データを算出する。

（3）算出した変数データに基づいて、回帰式の各変数の項の係数を 統計的に推定する。推定には、最小 2 乗法を使用する。

先行研究における投資によるエネルギー低減効果の計測は事例研 究が中心であるのに対し、本論では、新しい試みとして、標本とし

\footnotetext{
* 明海大学大学院不動産学研究科 博士後期課程 · 大学院生

** 明海大学不動産学部 教授・工博
} 
て選定された建物のクロスセクションデータから統計的に推定する ので、建物の個別事情を抑えた標準的な值を求めることができると 考えられる。

\section{2. 基本的な回帰式の考え方}

\section{1. 建物の竣工後に行われる投資のメカニズム}

竣工後投資のメカニズムに関して次の 2 つ考え方がある。この $2 つ$ 互いに対立するものではなく、竣工後投資を別の視点からと らえたものである。本論は主として (2)に依拠する。

（1）主として投資の経済性に着目する考え方

竣工後の投資は、投資案件の経済性の想定に応じて実行されると 考えることができる。経済性の想定とは、キャッシュフローや計画 期間など、投資案件の実行可否の判断要素をいう。経済性の想定は、 投資の種類が、(1)建物の収益力の維持向上を目的とする室内環境 · 機能・美観の改修か、(2)建物のエネルギー消費額の低減を目的とす る空気調和などの建築設備の改修か、(3)現有の部位・設備の物理的 劣化の回復を目的とする修繥か、等によって異なり、それに応じて、 投資のエネルギー低減効果も異なると考えられる。本論で用いる建 物の標本データでは、(1)、(2)、(3)のような種類別の投資額データを 把握することができない。

（2）主として劣化の回復に着目する考え方

竣工後の投資は、建物の何らかの種類の劣化の回復として実行さ れると考えることができる。劣化の種類には、物理的なもの、機能 的なもの、社会的なものが含まれる。本論で用いる建物の標本デー 夕では、これらの劣化種類別の投資額デー夕を直接には把握するこ とができないが、劣化に関する次のような性質を利用して、投資額 データの細分化計算を行い、ネルギー低減効果の計測を補強する。 既往研究では、社会的または機能的な劣化に対する投資が非周期的 であり関数としての定式化が容易でない一方、物理的劣化に対する 投資には周期性がある ${ }^{11)}$ という性質に着目し、時間の関数として

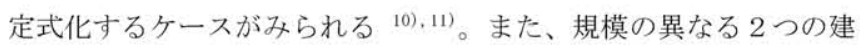
物があって、同じ種類で同程度の劣化を回復させるために投資を行 う場合、規模が大きい建物のほうが投資額が大きいことが多い。本 論では、これらの性質を利用し、投資額を被説明変数、時間（拨工 後年数) と規模（延面積）を説明変数として回帰分析を行うことに よって、各標本の投資額データを、時間と規模の関数として説明さ れる部分 (物理的劣化の回復のための投資を反映すると考えられる) と説明されない部分（建物仕様、使用状態、修䋛計画などに応じて 生じるもので、主として社会的・機能的劣化の回復のための投資を 反映すると考えられる）に計算分離（5. 参照）し、投資の種類別 のエネルギー低減効果を計測する (6. 参照) ことに役立てる。

\section{2. エネルギー純増額}

各建物の各期に消費されるエネルギーを金額表示でとらえ、これ を各期のエネルギー消費額と呼ぶ。各期のエネルギー消費額の実際 のデータとして、各期の水道光熱費を充てる。本論で用いる標本の データでは、水道光熱費を光熱費と水道費などに細かく分類するこ とはできず、水道光熱費をそのまま充てる。各期のエネルギー消費 額について、観測期間中の正味の増加額を 1 期あたり平均でみたも のを、エネルギー純増額と呼び、記号 $\Delta E$ で表す。ここで純増額と 呼ぶのは、時間の経過にしたがって各期のエネルギー消費額が増加 したり減少したりしても、その正味の増加額を示すためである。 $\Delta E$ の符号は正・負ともに可能性がある。 $\Delta E$ の符号が負となる場合は、 正味で低減したことを意味し、その絶対值をエネルギー低減額と呼 ぶ。 $\Delta E$ を実際のデータから算出する方法としては、次のものなど が考えられる。

(1) 観測期間における最終期のデータを第 1 期目のデータと比べ、 1 期あたりの平均の増減額を $\Delta E$ とする方法。

(2) 観測期間中におけるトレンド直線（期を説明変数とする回帰直 線）の勾配值を $\Delta E$ とする方法。この計算方法を、ある標本建物 を例として図 1 に示す。

(1) の方法では観測期間の途中の期のデータは $\Delta E$ の值に反映され ないが、（2）の方法では観測期間中のすべての期のデータが反映さ れるため、本論では(2)の方法を用いる (表 1 参照)。

\section{3. 投資のエネルギー低減効果}

各建物の各期の投資額の実際のデータとして、改修と修繥のため の各期の支出金額データをあてる。各期の投資額についての観測期 間中の 1 期あたり算術平均値を、単に投資額と呼び、記号 $I$ で表す

(表 1 参照)。 $\Delta E$ のうち $I$ によって生じる部分を $\Delta E^{I}$ で表す。 $\Delta E^{I}$ の符号は正・負ともに可能性がある。 $I$ に対する $\Delta E^{I}$ の比を $k\left(\equiv \Delta E^{I} / I\right)$ と定義する。Iは $\Delta E^{I}$ に対して比例的効果を持つと仮定 する。この仮定の下では $k$ は定数となる。 $k$ の符号は、正・負とも に可能性がある。とくに、符号が負のとき、 $k$ を投資のエネルギー 低減効果と呼ぶ。 $k$ は、投資額 $I$ 全体の平均的な効果を表す。

\section{4.収入純増によるエネルギ一純増効果}

$\Delta E$ に影響を与えるものとしては、I のほか、建物の稼働水準の 変動が考えられる。稼働水準の変動を表す変数注3) として、収入純 増額（記号 $\Delta R$ で表す）を用いる。 $\Delta R$ を実際のデータから算定する 方法は、 $\Delta E$ と同じく、観測期間中におけるトレンド直線の勾配值 を採用する (表 1 参照)。 $\Delta E$ のうち $\Delta R$ によって生じる部分を $\Delta E^{\Delta R}$ で表す。 $\Delta R$ は $\Delta E^{\Delta R}$ に対して比例的効果を持つと仮定し、その比例 定数を $h\left(\equiv \Delta E^{\Delta R} / \Delta R\right)$ と定義する。 $h$ の符号は通常は正である。

\section{5. 建物のエネルギー消費の変動を説明する基本的な回帰式}

$2.2 、 2.3 、 2.4$ によ、 $\Delta E$ は、

$\Delta E=c+\Delta E^{\Delta R}+\Delta E^{l}=c+h \cdot \Delta R+k \cdot l$
表 1 使用するデータの呼称とその值の算出方法

\begin{tabular}{|c|c|}
\hline データの呼称 & 値の算出方法 \\
\hline 各期のエネルギー消費額 & 各期の水道光熱費 \\
\hline エネルギー純増額（記号 $\Delta E$ ) & $\begin{array}{l}\text { 観測期間における各期のエネルギー消費額のトレンド直線 } \\
\text { の勾配值 }\end{array}$ \\
\hline エネルギー低減額 & エネルギー純増額の符号が負のときの絶対値 \\
\hline 各期の収入額 & 各期の賃貸事業収入額 \\
\hline 収入純増額（記号 $\Delta R$ ） & 観測期間における各期の収入額のトレンド直線の勾配値 \\
\hline 各期の投資額 & 改修または修繕のための各期の支出金額 \\
\hline 投資額 （記号 & 観測期間における各期の投資額の 1 期あたり算術平均値 \\
\hline
\end{tabular}

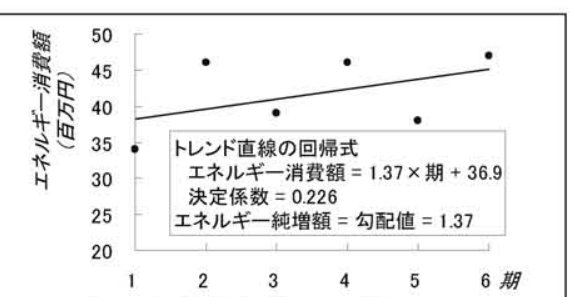

図 1 ある標本(観測期間 6 期)におけるトレ ンド直線(回帰直線)の勾配値計算の例示 
と表される。 $c$ は定数項である。さらに、誤差項 $u$ を加えて、式(2) のように、 $\Delta E$ を $\Delta R$ とIによって説明する回帰式を設定する。

$$
\Delta E=c+h \cdot \Delta R+k \cdot I+u
$$

$I$ の影響のみによるエネルギー純増額 $\left(\Delta E^{I}=k \cdot I\right)$ は観測でき ず、観測できるのは $I$ の影響と $\Delta R$ の影響が合計された全体として の $\Delta E$ である。そこで、 $k$ を計測するためには、 $\Delta R$ と $I$ にる重回 帰式である式(2)を構成して推定する必要がある。

誤差項 $u$ は、次の (1)、(2)の要因から構成される。(1)パラメータ $h$ お よび $k$ の誤差。 $h$ および $k$ は、それぞれ $\Delta R$ および $I$ による効果を 表し、回帰式では定数とみなすが、実際には建物の諸条件の違いに よって、 $h$ および $k$ には差異が生じ、誤差項の要因を構成する。(2) パラメータ $c$ の誤差。 $c$ は、仮に、投資が全くなく $(I=0)$ 、各期 の収入額の変動も全くない $(\Delta R=0)$ 場合であっても、各期のエネ ルギー消費額を変動させる要因を表す。各期のエネルギー消費額を 増加させる要因の例としては、建物・設備の自然劣化によるエネル ギー消費効率の低下が挙げられる。各期のエネルギー消費額を低減 させる要因の例としては、建物への投資によらず、運用上の工夫に よる取り組みが挙げられる。いずれも、建物ごとに事情が異なり、 誤差項の要因を構成する。

\section{3. 標本とする事務所建物とデータ \\ 3.1. 標本の選定の方法}

標本とする建物の選定の方法を表 2 に示す。 2007 年末時点を基準 とし、この時点で実際に稼働している事務所建物の中から選定寸る。 建物の用途を事務所建物のうち貸貸建物に限定したのは、貸貸事業 に関する決算情報により、本研究に必要な事務所建物に関するキャ ッシュフローの情報（各期のエネルギー消費額、収入額、投資額な

表 2 標本建物の選定方法

\begin{tabular}{|l|l|}
\hline 調査の基準時点 & 2007 年末 \\
\hline 用途・所在 & 賃貸事務所建物・東京23区内 \\
\hline 観測期間 & 基準時点からさかのぼって2年（4期）以 \\
\hline 上の決算情報が公開されていること \\
\hline 調査対象 & 不動産投資信託に組み込まれた不動産 \\
\hline
\end{tabular}

ど）を知ることができるからである。建物の所在地を東京 23 区内 に限定したのは、回帰式の推定において、都市圈の違いによる影響 が混入するのを防ぐためと、この地域から最も多くの標本建物が選 定できると期待されるからである。観測期間として、調查の基準時 点からさかのぼって 2 年以上の決算データが観測できることを条件 としたのは、各建物の各期のエネルギー消費額の増減傾向を把握す るためには 1 年間だけのデータでは十分ではないからである ${ }^{\text {住 }}$ 。 調査対象を不動産投資信託に組み込まれた不動産としたのは、個別 の不動産の賃貸事業の決算情報が公開されるからである 注5)。

\section{2. 選定された標本建物の延面積と竣工後年数}

表 2 の方法により、107 の事務所建物を標本として選定すること ができた。選定された標本の観測期間は図 2 に示すとおり、平均 3.5 年 $(7$ 期)、最長 6 年 $(12$ 期) である。

標本建物の基本的な属性として、延面積（記号 $S$ で表す）と竣工 後年数（記号 $A$ で表す）の度数分布と相関を図 3 に示す。延面積の 度数分布の平均は $6,687 \mathrm{~m}^{2}$ であり、 $5,000 \mathrm{~m}^{2}$ 以下の規模の標本が 62 個と全体の 5 割強を占めるが、標準偏差は $6,867 \mathrm{~m}^{2}$ 、最大は $36,764 \mathrm{~m}^{2}$ と、平均から大きく離れた標本もいくつか存在している。竣工後年 数 注 6) の度数分布の平均は 17 年であり、10 年以上 20 年末満の標 本数が 68 と全体の 6 割強を占めるが、標準偏差は 8 年、最大と最 小の幅 45 年と、平均から大きく離れた標本もいくつか存在してい る。延面積と竣工後年数の間の相関はほとんどなく、竣工後年数が 短いものほど規模が大きいなどの、標本選定の偏りは生じていない。

\section{4. 基本的な回帰式の推定}

\section{1. 各変数の度数分布}

各標本について算出されたエネルギー純増額 $\Delta E$ 、収入純増額 $\Delta R$ 、 投資額 $I$ のそれぞれの度数分布を図 4 に示す。 $\Delta E$ は、純増額 -1 百万円〜1 百万円とほどんど増減のない標本が 97 個と、全体の 9 割 を占めるが、これは、 $\Delta R$ による正の効果と、 $I$ による負の効果が 相殺されているためとみられる。 $\Delta R$ は平均 3.09 と、標本全体とし て、収入が増加していることを示している。 $I$ は、50 百万円以下の

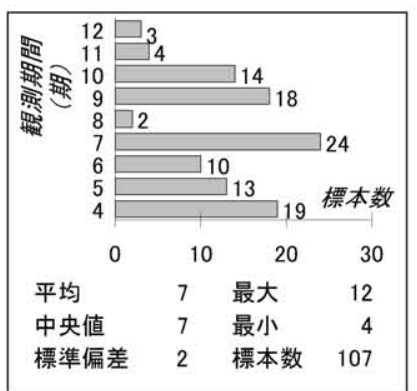

図 2 観測期間

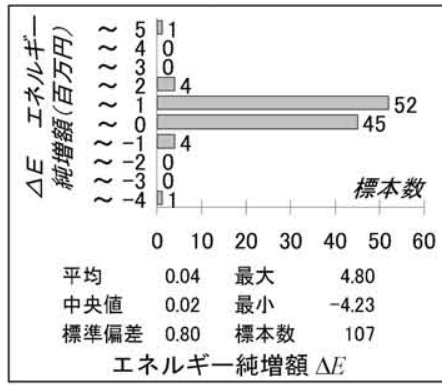

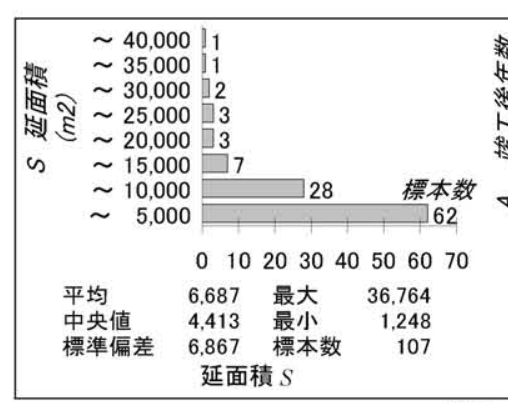

圈
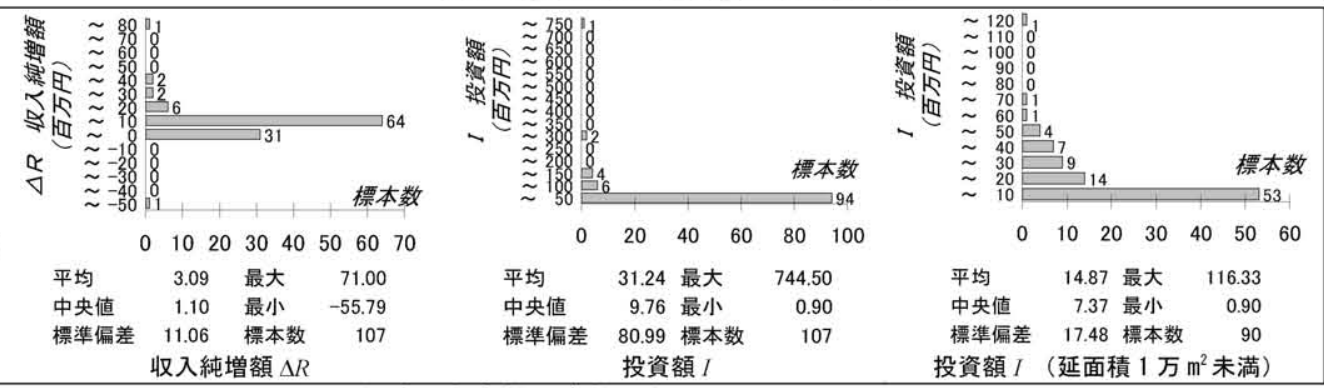

図 4 回帰式の各変数の度数分布 
標本が 94 個と、全体の 9 割近くを占めるが、平均から非常に大き く離れた標本デー夕も存在する。これは、図 3 に示した延面積が平 均から大きく離れた標本がいくつか存在することを反映している。 $I$ については、延面積 1 万 $\mathrm{m}^{2}$ 未満の 90 個の標本のみでの度数分布 も併せて示しているが、投資額の小さい標本の数が多い傾向は、全 107 標本の場合と同じである。

\section{2. 変数間の相関係数}

変数間の相関係数を図 5 に示す。被説明変数と説明変数の間の相 関係数については、 $\Delta E$ と $\Delta R$ 間で正 $(0.376) 、 \Delta E$ と $I$ 間で負 $(-0.550)$ となり、回帰式の想定と一致した。一方、2つの説明変 数 $\Delta R$ と I間の相関係数は、ほぼゼロ $(-0.003)$ となった 注 7$)$ 。説 明変数間に相関がないことから、回帰式の推定において、多重共線 性による影響はないと判断される。

\section{3. 基本的な回帰式の推定}

式(2)の最小 2 乗法による推定結果を表 3 に示す。

説明変数 $\Delta R$ および $I$ の各係数は有意に推定され $(t$ 值はそれぞれ $5.11,-7.50$ であり、有意性の目安である絶対值 2 を十分上回って いる)、定数項を除く各係数の符号条件も想定と一致している。投資 のエネルギー低減効果は、 $I$ の係数 $k$ の推定值として、 $-5.43 \times 10^{-3}$ （約－0.54\%）と計測された。投資額 1 百万円に対するエネルギー 低減額が 5 千円であることを示している。この結果は、表 2 に示し た標本建物 107 物件を対象とした範囲におけるものである。

\section{5. 投資額の分析}

投資額 $I$ と延面積 $S$ の間の相関、投資額 $I$ と竣工後年数 $A$ の間の 相関を図 6 に示す。いずれも正の相関がある。これから、投資額の 中に延面積と竣工後年数の関数として定式化できる部分が含まれて いることが示唆されている。この性質を利用して、標本間の投資額 の差異を、延面積と竣工後年数に応じた差異と、それ以外の要因に 基づく差異とに分離する計算を行う。分離された各部分のエネルギ 一低減効果の計測は6.で行う。

\section{1. 投資額を延面積と竣工後年数で説明する回帰式}

投資額を、延面積と竣工後年数によって説明する回帰式を作成し て推定する。その準備として、改めて、投資額 $I$ 、延面積 $S$ 、拨工 後年数 $A$ の関係を、図 7 に示す。この図では、全標本を、投資額 $I$ の大きさの範囲に応じて 5 つのグループ（[1]〜 [5]）に分け、各々 のグループごとに異なる表示記号をつけて、延面積 $S$ と竣工後年数 $A$ との対応する位置に示している。グループ間の位置関係をみると、 例えば、グループ[1]（投資額 $I<5$ 百万円）の標本の位置と、グル

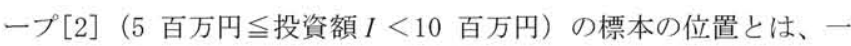

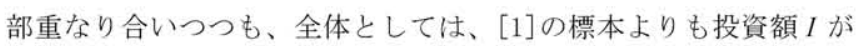
大きい[2]の標本のほうが、延面積 $S$ が大きいか、竣工後年数 $A$ が 長い位置に示されている (図 7 の楕円形の囲みの位置を参照)。他 のグループ間（[2]と [3]、 [3]と [4]、[4]と [5]の間）の位置関係に ついても、同様のことが示されている。

図 7 は、標本全体の傾向として、延面積 $S$ が大きいほど、また、 竣工後年数 $A$ が長いほど、投資額 $I$ が大きいことを示唆する。これ に基づき、投資額 $I$ 、延面積 $S$ 、竣工後年数 $A$ の間に、

$$
I=\alpha \cdot S^{x} \cdot A^{y}
$$

の関倸があると仮定する 注 ${ }^{8)}$ 。パラメータ $\alpha, x, y$ はすべて正の定数 とする。式(3)の両辺を対数変換し、誤差項 $\varepsilon$ を加えた線形回帰式 $\ln I=\ln \alpha+x \cdot \ln S+y \cdot \ln A+\varepsilon \quad(\ln :$ 自然対数 $)$ を最小 2 乗法により推定した結果を次に示す。

$$
\begin{aligned}
& \ln I=\ln \left(4.87 \times 10^{-5}\right)+1.12 \cdot \ln S+1.08 \cdot \ln A+\hat{\varepsilon} \\
& \text { [ } t \text { 值 }] \quad[-12.4] \quad[13.1] \quad \text { [9.35] }
\end{aligned}
$$$$
\text { 自由度調整済決定係数 }=0.703 \quad \hat{\varepsilon} \text { : 残差 }
$$

各係数は有意に推定され、符号条件も想定と一致している。

\section{2. 投資額の分離計算}

式(5)による予測值を $I b$ とし、実績值 $I$ との差を $I v$ とおくと、

$$
\begin{aligned}
I b & =4.87 \times 10^{-5} \cdot S^{1.12} \cdot A^{1.08} \\
I & =I b+I v
\end{aligned}
$$

である。各標本の $I 、 I b 、 I v$ の值を、 $S$ および $A$ と対応させてプ ロットしたものを図 8 に示す。

投資額 $I$ を構成する $I b$ と $I v$ の值の意味を次に述べる。予測值 $I b$

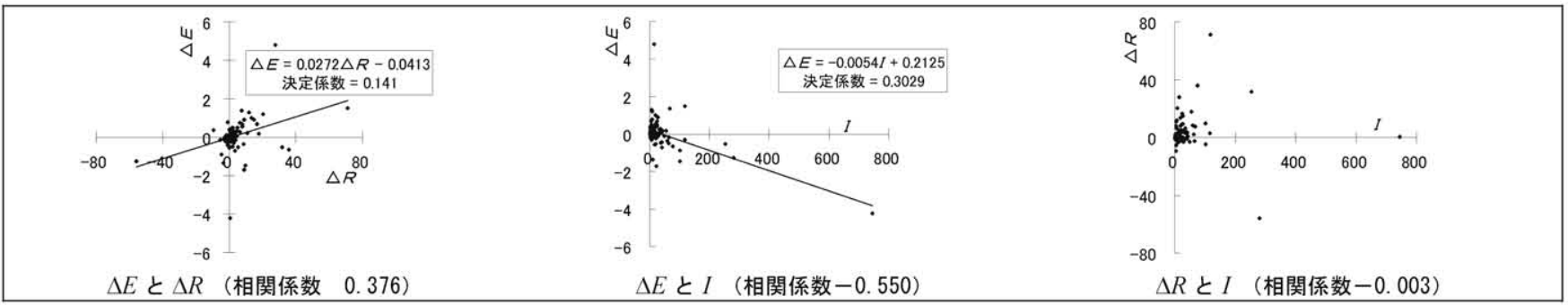

図 5 回帰式の各変数の間の相関

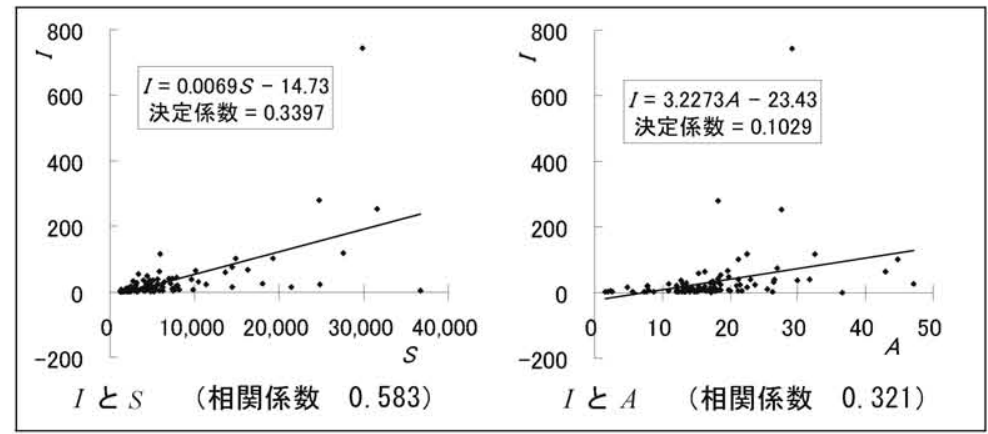

図 6 投資額 $I$ と延面積 $S$ 、竣工後年数 $A$ の間の相関

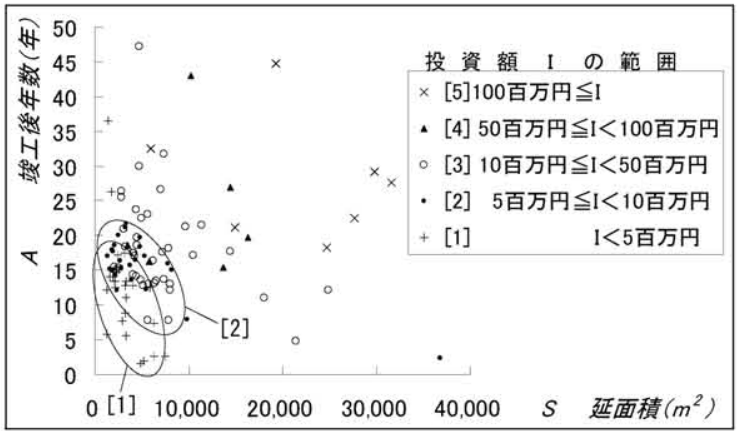

図 7 投資額 $I$ 、延面積 $S$ 、竣工後年数 $A$ の関係 
の值は、延面積 $S$ 、竣工後年数 $A$ に応じた標準的な投資額を表す。 予測值と実績值との差である $I v$ の值は、その標淮的な值からの乘離 額を表しており、その乘離は、建物仕様、使用状態、修繕計画など の違いに応じて生じると考えられる。

式(6)および式(7)により求められた $I b$ と $I v$ の值を利用すること により、標本間の投資額 $I$ の差異が、延面積と竣工後年数に応じた 差異と、それ以外の要因に基づく差異との和として表されることを 次に示す。 2 つ標本 $i$ と $j$ について、式(7)により、

$$
\begin{aligned}
& I_{i}=I b_{i}+I v_{i} \\
& I_{j}=I b_{j}+I v_{j}
\end{aligned}
$$

が成り立つ（各式の添字は標本の区別を表す）から、式(8)の両辺 から式(9)の両辺を差し引いて

$$
\left(I_{i}-I_{j}\right)=\left(I b_{i}-I b_{j}\right)+\left(I v_{i}-I v_{j}\right)
$$

すなわち、

$$
\text { (Iの差異) }=(I b \text { 差異 })+(I v \text { の差異 })
$$

が得られる。標本間における $\mathrm{Ib}$ の差異は、延面積または竣工後年数 が標本間で異なることに基づいて生じる。標本間における $I v$ の差異 は、仮に延面積と竣工後年数が全く等しい 2 つの建物があるとして も、それぞれの建物仕様、使用状態、修繥計画などの違いにより、 投資額に差が生じることを意味する。

\section{6. 延面積と竣工後年数を考慮した回帰式}

5. で行った投資額の分離計算の考え方 (式(11)) を利用して、式 （2）を修正し、延面積と竣工後年数の違いに応じた投資額によるエ ネルギー低減効果と、その他の要因に基づく投資額の変動によるエ ネルギー低減効果とを、区別して計測する。

式(2)を、I の代わりに、 $I b$ と $I v$ を用いて、

$$
\Delta E=c+h \cdot \Delta R+k_{1} \cdot I b+k_{2} \cdot I v+e
$$

と書き換える。 $e$ は誤差項である。この回帰式の推定によって、投 資のエネルギー低減効果を、延面積と竣工後年数の差異に基づく投 資額の差異によって生じる効果 $k_{1}$ と、建物仕様、使用状態、修縜計 画の違いなどに基づく投資額の差異によって生じる効果 $k_{2}$ とに、分 離して計測することができる。

式(12)の最小 2 乗法による推定結果を表 3 に示す。すべての係数 が有意に推定され、符号条件は想定と一致した。 $I b$ のエネルギー低 減効果は-8. $63 \times 10^{-3}$ と、式(2)の $I$ の効果よりも絶対值として大き い值が計測された。 Iv のエネルギー低減効果は-3. $82 \times 10^{-3}$ と、式 (2)のIの効果よりも絶対值として小さい值が計測された。これら の結果は、投資によるエネルギー低減効果が均一ではなく、延面積 と竣工後年数の違いに応じた投資額の差異は、その他の要因に基づ
く投資額の差異よりも、大きいエネルギー低隇効果をもつことを示 している。

\section{7. 残差の分析と回帰式の修正}

式(12)の推定結果により計算される残差 $\hat{e}$ の絶対値 $|\hat{e}|$ と、延面積 $S$ の相関を図 9 に示す。相関係数は 0.530 であり、かなり強い正の 相関がある。誤差項の分散に不均一性が生じている可能性がある。 $|\hat{e}|$ を延面積 $S$ で説明する線形式を最小 2 乗法により推定した結果 を図 9 の中に示す。延面積 $S$ の倸数は有意に推定された $(t$ 值 6.40) が、定数項は有意とならなかった（ $t$ 值 1.43$)$ 。誤差項の分散の不 均一性を取り除いた推定を行うため、式(12)の両辺を $S$ で除して

$$
\frac{\Delta E}{S}=c \cdot \frac{1}{S}+h \cdot \frac{\Delta R}{S}+k_{1} \cdot \frac{I b}{S}+k_{2} \cdot \frac{I v}{S}+e^{\prime}
$$

と書き換える。 $e^{\prime}$ は誤差項である。比較のために、式(2)の両辺を $S$ で除した、次式についても推定する。 $u^{\prime}$ は誤差項である。

$$
\frac{\Delta E}{S}=c \cdot \frac{1}{S}+h \cdot \frac{\Delta R}{S}+k \cdot \frac{I}{S}+u^{\prime}
$$

回帰式の両辺を $S$ で除したのは、誤差項の分散の不均一性を取り 除いた推定を行うためであるが、 $\Delta E / S$ の実際的な意味は、建物の 床面積単位あたりでみたエネルギー純増額である。

式(14)および式(13)の最小 2 乗法による推定結果を表 3 に示す。

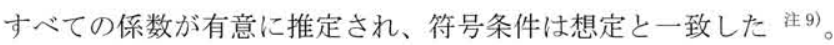

式(13)の Ib/S のエネルギー低減効果は-6. $47 \times 10^{-3}$ となり、式 (14)の $I / S$ の効果 $\left(-5.06 \times 10^{-3}\right)$ よりも、絶対值として大きい值が 計測された。式(13)の $I v / S$ のエネルギー低減効果は $-4.29 \times 10^{-3}$ と、 式(14)の $I / S$ の効果よりも絶対值として小さい值が計測された。こ れらの結果は、延面積と竣工後年数の違いに応じた投資額の差異は、 その他の要因に基づく投資額の差異よりも、大きいエネルギー低減 効果をもつことを示しており、式(2)および式(12)の推定結果と同 様の結果が得られた。

\section{8. 標本の限定による推定}

表 2 の標本建物 107 物件に関寸る表 3 の回帰式の推定は、有意な 推定結果となったが、標本を、建物規模（延面積）や観測期間など によって限定することにより、より有意な計測結果を得られる可能 性があるため、その検討を行った。今回は次のとおり標本を限定し たうえで計測し、結果を吟味した。計測結果を表 4 に示す。

(1) 延面積による標本の限定

延面積の違いによって投資のエネルギー低減効果が異なる可能性 が考えられる。表 2 の標本では、延面積の最大は $36,764 \mathrm{~m}^{2}$ である が、全体の約 9 割が延面積 1 万 $\mathrm{m}^{2}$ 以下である。延面積の大きい少数

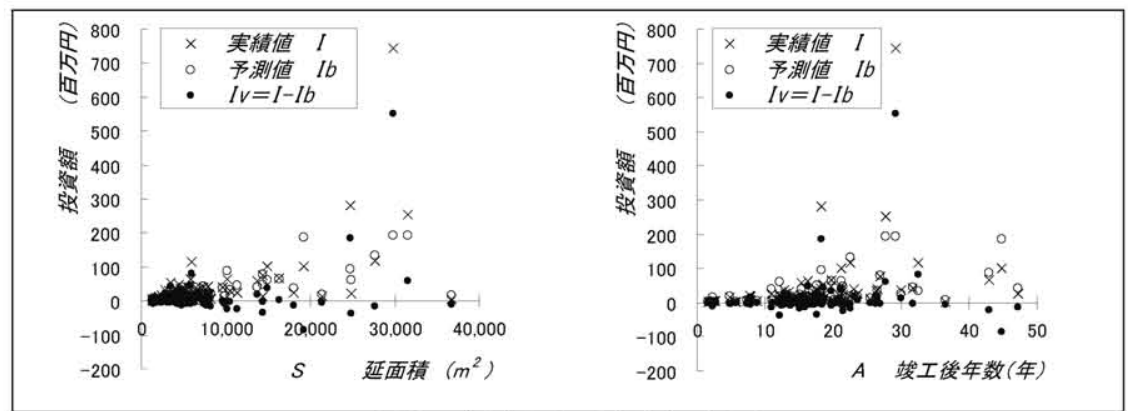

図 8 式(6)および式(7)の図示

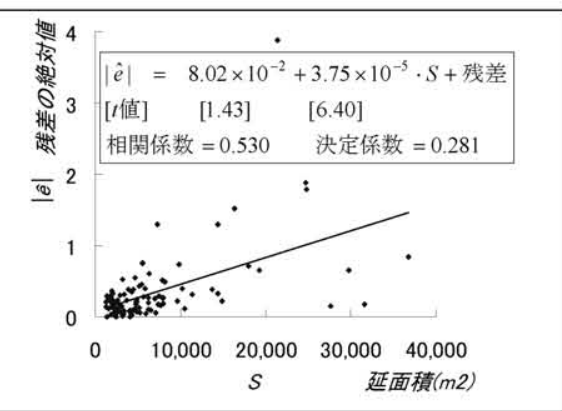

図 $9|\hat{e}|$ と延面積 $S$ の相関 
の標本が推定結果に影響を与えている可能性があるため、今回は、 延面積 1 万 $\mathrm{m}^{2}$ 以下のもの（標本数 90）のみについて、式(2)の推定 を行った。す心゙ての説明変数の係数が有意に推定され、符号条件は 想定と一致した。 $I$ の係数の $t$ 值が標本数 107 の場合より小さくな ったことは、延面積の大きな標本を取り除いたために説明変数 $I$ の データの散らばりが全体として小さくなったことによるものと考え られる。投資のエネルギー低減効果は標本数 107 の場合よりも大き い值として計測された。これは、延面積が大きく投資のエネルギー 低減効果が比較的小さい少数の標本が除かれたためと考えられる。

(2) 竣工後年数による標本の限定

竣工後年数の違いによって投資のエネルギー低減効果が異なる可 能性が考えられる。例えば、竣工直後の数年間は、本格的な投資は あまり行われないのが一般的であると思われる。そこで、今回は竣 工後 10 年以内のものを除き、10 年超のもの（標本数 93）のみにつ いて式(2)の推定を行った。結果は、すべての説明変数の係数が有 意に推定され、符号条件は想定と一致した。また $I$ の係数の $t$ 值が 標本数 107 の場合より大きく、より有意な推定結果が得られた。こ の結果は、竣工後 10 年超の建物ではそれ以前のものよりも投資が 本格的に行われることを反映していると考えられる。

\section{（3）観測期間による標本の限定}

各期の投資額が各期のエネルギー消費額の変動に及ぼす効果は 1 期ごとに完結するのではなく、時間的遅れを伴うと考えられるため、 観測期間が長いほど、より有意な推定結果が得られる可能性がある。 そこで今回は、観測期間が 4 期または 5 期の標本を取り除き、観測 期間 6 期 (3 年) 以上の標本（標本数 75）のみについて式(2)の推 定を行った。結果は次のとおりである。 $I$ の係数は有意に推定され、 符号条件は想定と一致した。 $I$ の係数の $t$ 值は標本数 107 の場合よ り大きく、より有意な推定結果となった。この結果は、各期の投資 額の効果の時間的遅れをカバーするには、観測期間が長いものほど 有利であることを示している。 $\Delta R$ の係数は有意とならなかった。 このことは、各期の収入額の変動が各期のエネルギー消費額の変動 に与える効果は、投資額の場合のような大きな時間的遅れを伴うも のではない可能性を示唆しているものと思われる。

9. 結論

表 3 回帰式の推定結果一覧（標本数 107）

\begin{tabular}{|c|c|c|c|c|c|c|}
\hline \multirow[b]{3}{*}{ 項目 } & \multicolumn{3}{|c|}{ 式(2) } & \multicolumn{3}{|c|}{ 式(12) } \\
\hline & \multicolumn{3}{|c|}{ 被説明変数 $\Delta E$} & \multicolumn{3}{|c|}{ 被説明変数 $\Delta E$} \\
\hline & 説明変数 & 係数値 & $t$ 値 & 説明変数 & 係数値 & $t$ 值 \\
\hline- & 定数項 & $1.29 \times 10^{-1}$ & 1.99 & 定数項 & $1.72 \times 10^{-1}$ & 2.49 \\
\hline 収入純增額 & $\Delta R$ & $2.71 \times 10^{-2}$ & 5.11 & $\Delta R$ & $3.19 \times 10^{-2}$ & 5. 34 \\
\hline \multirow{2}{*}{ 投資額 } & \multirow[b]{2}{*}{ I } & \multirow{2}{*}{$-5.43 \times 10^{-3}$} & \multirow{2}{*}{-7.50} & $I b$ & $-8.63 \times 10^{-3}$ & -4.27 \\
\hline & & & & Iv & $-3.82 \times 10^{-3}$ & -3.21 \\
\hline \multirow[t]{3}{*}{ 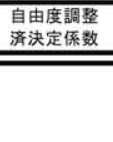 } & \multicolumn{3}{|c|}{0.432} & \multicolumn{3}{|c|}{0.442} \\
\hline & \multicolumn{3}{|c|}{ 式(14) } & \multicolumn{3}{|c|}{ 式(13) } \\
\hline & \multicolumn{3}{|c|}{ 被説明変数 $\Delta E / S$} & \multicolumn{3}{|c|}{ 被説明変数 $\Delta E / S$} \\
\hline 項目 & 説明変数 & 係数値 & $t$ 値 & 説明変数 & 係数値 & $t$ 值 \\
\hline- & $1 / S$ & $6.61 \times 10^{-2}$ & 2. 63 & $1 / S$ & $7.38 \times 10^{-2}$ & 2.55 \\
\hline 収入純増額 & $\Delta R / S$ & $3.62 \times 10^{-2}$ & 5.20 & $\Delta R / S$ & $3.70 \times 10^{-2}$ & 5.18 \\
\hline \multirow{2}{*}{ 投資額 } & \multirow{2}{*}{$I / S$} & \multirow{2}{*}{$-5.06 \times 10^{-3}$} & \multirow{2}{*}{-3.26} & $\mathrm{Ib} / \mathrm{S}$ & $-6.47 \times 10^{-3}$ & -2.13 \\
\hline & & & & $\mathrm{Iv} / \mathrm{S}$ & $-4.29 \times 10^{-3}$ & -2.02 \\
\hline 自由度調整 & \multicolumn{3}{|c|}{0.220} & \multicolumn{3}{|c|}{0.215} \\
\hline
\end{tabular}

本論では、投資のエネルギー低減効果を、建物の竣工後において 行われる投資額に対する、その投資によって生じるエネルギー低減 額の比、として定義したうえで、投資のエネルギー低減効果をパラ メータとして含む回帰式を、実際に稼働している賃貸事務所建物の 標本データに適用することによって推定し、投資のエネルギー低減 効果の計測を行い、表 3 の結果を得た 注10)。この結果は、表 2 に示 した標本建物 107 物件を対象とした範囲におけるものである。計測 を通じて明らかにしたことを次に記す。これらの分析により、既存 の事務所建物の投資が省エネルギーにどれだけ貢献しているかを知 るための一つの基礎的資料を提供することができたと考える。

（1）エネルギー純増額を収入純増額と投資額によって説明する基 本的な回帰式 (式 (2)) を線形の関数形で作成し、推定した結果、 投資のエネルギー低減効果は、回帰式における投資額の係数とし て、 $-5.43 \times 10^{-3}$ (約 $-0.54 \%$ ） と計測された。投資額 1 百万円に 対するエネルギー低减額が 5 千円であることを示している。式 (2)

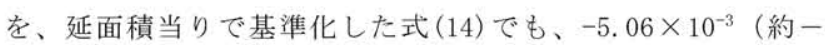
$0.51 \%$ ）と、ほぼ同じ水準の值が得られた。

（2）投資によるエネルギー低減効果は、投資額全体を通じて均一で はなく、投資の種類によって異なる可能性があるから、（1）を補 強する資料とするため、投資の種類別のエネルギー低減効果を計 測することを試みた。そのために、まず、投資額を延面積と竣工 後年数によって説明する回帰式を累乗の関数形で作成し、推定し た結果、自由度調整済決定係数でみて 7 割程度が、延面積と竣工 後年数によって説明された。

この結果を利用して、各標本の投資額を、回帰式の予測值部分 $(I b)$ と残差部分 $(I v)$ とに分解し、各々の部分のエネルギー 低減効果を計測した (式 $(12))$ 。この結果、 $I b$ は $I v$ よりも大きい エネルギー低減効果をもつことが示された。式(12)を、延面積当 りで基準化した式(13)でも、同様のことが示された。

標本間の $I b$ の差異は、物理的劣化の回復のための投資額の標本 間差異を反映し、標本間の $I v$ の差異は、建物仕様、使用状態、修 繥計画などの差異に応じて生じるもので、主として社会的・機能 的劣化の回復のための投資額の差異を反映すると考えられる。 $I v$ のエネルギー低減効果が $I b$ より小さい值となった背景として、今 回の表 2 の標本では、社会的・機能的劣化に対する投資額の中に、 建物のエネルギー消費額の低減を目的とする空気調和などの建 築設備の改修等に対する投資だけでなく、建物の収益力の維持向 上を目的としエネルギー消費額を低減させる効果はない室内環 境・機能・美観の改修等に対する投資も多く含まれ、その結果、 社会的・機能的劣化に対する投資額全体の平均的なエネルギー低 減効果が低い值になった可能性が考えられる。

（3）標本を一定の条件で限定することにより、式(2)について、よ り有意な計測結果を得られる可能性を検討し、表 4 の結果を得た。

表 4 標本を限定した場合の式(2)の推定結果

\begin{tabular}{|c|c|c|c|c|c|c|}
\hline 標本条件 & \multicolumn{2}{|c|}{ 延面積 $10,000 \mathrm{~m}^{2}$ 以下 } & \multicolumn{2}{|c|}{ 竣工後年数 10 年超 } & \multicolumn{2}{|c|}{ 観測期間 6 期以上 } \\
\hline 標本数 & \multicolumn{2}{|c|}{90} & \multicolumn{2}{|c|}{93} & \multicolumn{2}{|c|}{75} \\
\hline 説明変数 & 係数値 & $t$ 値 & 係数値 & $t$ 値 & 係数値 & $t$ 值 \\
\hline 定数項 & $6.66 \times 10^{-2}$ & 1.63 & $8.13 \times 10^{-2}$ & 1.59 & 7. $45 \times 10^{-2}$ & 1. 31 \\
\hline$\Delta R$ & $4.81 \times 10^{-2}$ & 6.57 & $1.82 \times 10^{-2}$ & 4. 44 & 3. $70 \times 10^{-3}$ & 0.661 \\
\hline$I$ & $-6.18 \times 10^{-3}$ & -3.45 & $-5.22 \times 10^{-3}$ & -9.70 & $-5.42 \times 10^{-3}$ & -9.78 \\
\hline 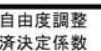 & \multicolumn{2}{|c|}{0.340} & \multicolumn{2}{|l|}{0.549} & \multicolumn{2}{|l|}{0.563} \\
\hline
\end{tabular}


竣工後年数、観測期間について一定の限定条件を付すことにより、 投資額の係数についてより有意な推定值を得ることができた。

注

注1）建物運用時のエネルギーを低減させるための建物新設前の設計段階に おいて行われる取り組みを扱った研究例を掲げる。葆谷ら ${ }^{1}$ は、コージェ ネレーションシステムについて、設計負荷と実際負荷の乘離のいくつかの パターンごとに成績係数が受ける影響を示したうえで、設計の違いによる 影響の受け方の違いを考察している。河合ら゙2 は、蓄熱式空調システムに ついて、予測精度の異なる 4 種類の熱負荷予測手法と蓄熱槽の 6 種類の設

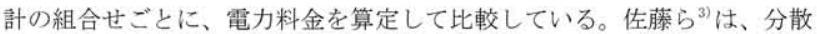
型熱源方式であるビル用マルチエアコンについて、空調空間の熱環境と設 備挙動実態を観測し、適切な熱環境とエネルギー低減の観点から、設計を 検討している。

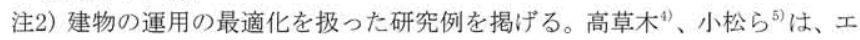
ネルギー消費量や外気温度の関係の統計解析を通じて、運用の最適化のた めの基礎資料の提供を試みている。早川 $5^{6}$ ( は、建物の条件・使用状態 · 気象条件のデータに基づく理論計算と統計解析により、エネルギー原単位 目標値を算出するソフトウェアの開発について研究している。佐藤ら ${ }^{3)}$ は、 観測結果に基ついて、設備挙動の把握のための評価指標を提案している。

注3）建物の稼働水準の変動を表寸指標として、稼働率（建物の延面積のうち 実際に賃貸されている面積の割合）も考えられるが、稼働率は $100 \%$ に達寸 ると、それを超える業務繁忙度の上昇を表すことができない。

注4）観測期間の最低条件を、どの程度長くとれば十分かについての一律の基 準はないが、この条件を長くとるほど、それに応じて、利用できる標本数 は少なくなる。今回の分析では、標本数の減少を防ぐために、2 年間のデ ータがあればよいものとした。

注5）不動産投資信託（REIT：Real Estate Investment Trust）に組み込まれ た不動産を対象として標本を選定した理由は、データの利用可能性の観点 だけであり、もし、同じ基準（用途、所在、観測期間、データ項目）でデ 一夕が利用できる建物があれば、必ずしも REIT に組み込まれた不動産であ る必要はない。

注6) 竣工後年数は、竣工した時点からの経過年数であり、数年にわたる観測 期間中のどの時点までで計算するかの基準を決める必要がある。本論では、 観測期間の中間時点までとして計算した。

注7）収入純増額 $\Delta R$ と投資額 $I$ の間に相関がないことの現実的な意味とし ては、建物の収益性の維持向上を目的とする投資を行っても、収入額は他 の建物との相対的競争条件に大きく影響されるために、必ずしも収入額が 増加するとは限らないことが考えられる。

注8) 建物の劣化量が [経過時間] ${ }^{\mathrm{y}}$ の型で表される劣化関数（指数yは劣化進行 の型を表すパラメータ)や、これに基づく修繥量または修繥費については、 これまでに多くの研究が行われている(文献10)、11)、12)など)。本研究 の特徴は、この型の関数（式(3)) を、複数の建物のクロスセクションデー 夕に適用し、よく当てはまることを示した（式(5))ことである。

注9）式(14)および式(13)の自由度調整済決定係数は、式(2)および式(12) と 比べて低い。これは、誤差項の分散の不均一性を取り除くために回帰式の 両辺を延面積 $S$ で除することにより、比較的延面積の小さい標本の残差の 絶対值が相対的に大きくなり、延面積の大きい標本の残差の絶対值が相対 的に小さくなるが、今回の標本に比較的延面積の小さい建物が多く含まれ ていることから、全体として、残差の絶対值が大きくなるためである。

注10）回㷌式の各変数のデータの算出にあたり、次の事情に配慮し、物価指 数によるデフレートを行っていない。各期の投資額やエネルギー消費額の 中には、様々な種類の商品・サービスが含まれ、その内訳構成比は、標本 建物ごとに異なり、また、同じ商品・サービスであっても、標本建物ごと に購入価格が異なる可能性があると考えられる。したがって、各標本建物 のデータを、物価指数によって適切にデフレートすることは実際上難しい。 このような事情があるものの、各期のエネルギー消費額については、物価 変動の影響を取り除くか否かによって、本研究の目的である投資のエネル ギー低減効果の計測結果に大きな影響を及ぼす可能性があるため、補足的 に、表 3 の各回帰式について、各期のエネルギー消費額を物価指数により デフレートしたデータを用いての計測も実施した。使用した物価指数は、 日本銀行「企業物価指数 2005 年基淮」の「国内企業物価指数」のうち、類 別「電力・都市ガス・水道」の暦年半期データである。このデータに基づ いて各回帰式の推定を行った結果を表 5 に示す。式(2)、式(14)における
投資のエネルギー低減効果は、表 3 の結果よりも絶対值としてわずかに大 きい值となった。式(12)、式(13)の推定結果では、 $I b$ は $I v$ よりも大きい エネルギー低減効果をもつことが示され、表 3 と同様の結果となった。

表 5 回帰式の推定結果（エネルギー消費額を物価指数で

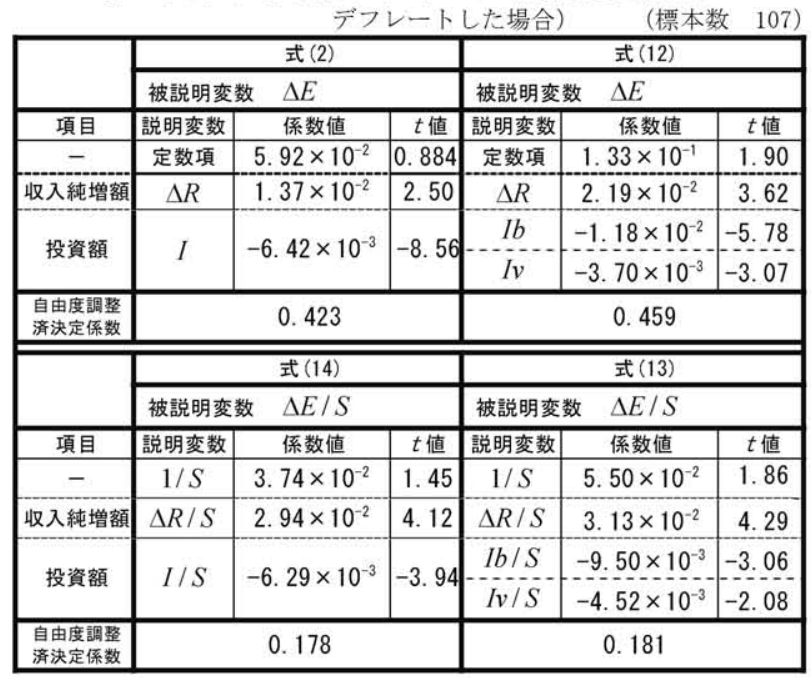

\section{参考文献}

1) 藥谷 至誠, 藤井 修二, 湯浅 和博, 植草 常雄, 室田 幸子：建物負 荷の変化と設計要素がコージェネレーションシステムの省エネルギー性に 及ぼす影響，日本建築学会計画系論文集，第 531 号, pp. 59-66，2000.5 2) 河合 和彦, 相楽 典泰，武田 仁，植木 智之，松田 聡浩：蓄熱式空 調システムの熱負荷予測精度が熱源機器の電力消費量および電力料金に及 ぼす影響，日本建築学会計画系論文集，第 537 号，pp. 77-84，2000.11

3) 佐藤 孝輔, 橋本 哲, 坂本 雄三：大規模空調空間を複数の室内機で分 担処理するビル用マルチェアコンの挙動実態とその評価手法 : ビル用マル チエアコンの最適運用・最適設計に関する調查研究 (その1), 日本建築学 会環境系論文集，第 618 号, pp. 85-92，2007.8

4) 高草木 明：中小規模賃貸事務所建物の電気使用量の実態とその変動要因 に関する調查研究, 日本建築学会計画系論文集, 第 554 号, pp. 101-108, 2002. 4

5) 小松 正佳，高草木 明：中規模賃貸事務所ピルにおける熱使用量の実態 調查研究, 日本建築学会環境系論文集, 第 593 号, pp. 57-64, 2005.7

6) 早川智, 小峯裕己, 猪岡達夫, 渡辺健一郎, 石黒邦道, 佐藤孝 輔：事務所ビル用エネルギー消費原単位管理ツール：エネルギー消費原 単位管理ツールの開発その 1 , 日本建築学会環境系論文集, 第 616 号, pp. 91-98, 2007.6

7) 住吉 大輔，赤司 泰義，渡辺 俊行，神村一幸，西山 紀光，崔 軍 : 空調システムの運用における熱源インバータ制御の省エネルギー効果, 日 本建築学会環境系論文集, 第 595 号, pp. 73-81, 2005.9

8) 水田 和彦，伊香賀 俊治，村上 周三：ウレタン壁内注入と空の断熱改 修効果の 2020 年までの予測：住宅の断熱改修による温室効果ガス排出削 減に関する研究, 日本建築学会環境系論文集, 第614 号, pp. 99-106, 2007.4

9) 杉田 洋，関 五郎，村川三郎：事務所建物のリニューアルによる環境 負荷低減とその対費用効果に関する基礎的研究, 日本建築学会計画系論文 集，第 584 号, pp. 137-144, 2004. 10

10) 古阪 秀三：維持保全計画の計量的方法に関する研究, 日本建築学会計 画系論文報告集，第 368 号, pp. 147-156, 1986. 10

11）村上公哉，尾島 俊雄，竹林 芳久, 高部 素行：建物の保全費用か らみた物理的要因の機能劣化に関する研究, 日本建築学会計画系論文報告 集, 第 418 号, pp. 115-124, 1990.12

12）菊地文人, 石坂 公一, 近江隆 : 建物の長期修繕計画の基本モデル に関する一考察, 日本建築学会計画系論文集, 第 561 号, pp. 225-231, 2002. 11

(2009年 10 月 9 日原稿受理，2010年 3 月 4 日採用決定) 